Vol. 15 (2006): 61-72.

\title{
Insect pests and their natural enemies on spring oilseed rape in Estonia: impact of cropping systems
}

\author{
Eve Veromann, Tiiu Tarang, Reelika Kevväi, Anne Luik \\ Institute of Plant Protection, Estonian Agricultural University; Kreutzwaldi 64, Tartu 51 014, Estonia, \\ e-mail:eve.veromann@loodusfoto.ee
}

Ingrid Williams

Rothamsted Research, Harpenden, Hertfordshire AL5 2JQ, United Kingdom

\begin{abstract}
To investigate the impact of different cropping systems, the pests, their hymenopteran parasitoids and predatory ground beetles present in two spring rape crops in Estonia, in 2003, were compared. One crop was grown under a standard (STN) cropping system and the other under a minimised (MIN) system. The STN system plants had more flowers than those in the MIN system, and these attracted significantly more Meligethes aeneus, the only abundant and real pest in Estonia. Meligethes aeneus had two population peaks: the first during opening of the first flowers and the second, the new generation, during ripening of the pods. The number of new generation M. aeneus was almost four times greater in the STN than in the MIN crop. More carabids were caught in the MIN than in STN crop. The maximum abundance of carabids occurred two weeks before that of the new generation of M. aeneus, at the time when M. aeneus larvae were dropping to the soil for pupation and hence were vulnerable to predation by carabids.
\end{abstract}

Key words: spring oilseed rape, pollen beetles, Hymenoptera, Carabidae

\section{Introduction}

In Estonia, the cultivation of oilseed rape (Brassica napus L., Brassica rapa L.) has expanded greatly in recent years and now exceeds 46,300 ha (Statistics Board 2003). This provides good potential for population growth of crucifer-specialist, phytophagous pests. In Europe, the most common pests of oilseed rape are Meligethes aeneus (Fab.), Meligethes viridescens (Fab.) (pollen beetles), Ceutorhynchus assimilis (Payk.) (cabbage seed weevil), Ceutorhynchus pallidactylus (Marsham) (cabbage stem weevil), Ceutorynchus napi Gyll. (rape stem weevil), Dasineura brassicae (Winn.) (brassica pod midge), Psylliodes chrysocephala (L.)(cabbage stem flea beetle) and Phyllotreta nemorum (L.), Phyllotreta undulata (L.) and Phyl- 
Veromann, E. et al. Oilseed rape insects in Estonia

lotreta diademata $(\mathrm{L}$.$) (flea beetles) (Alford et al.$ 2003).

The management of pests on oilseed rape throughout Europe still relies heavily on chemical pesticides, most often applied routinely and prophylactically, often without regard to pest incidence (Williams 2004). This leads to the over-use of pesticides, which reduces the economic competitiveness of the crop and threatens biological diversity. The pesticides also kill the natural agents of biological control, which would be a natural resource of great potential benefit to the farmer and the consumer (Alford et al. 1995, Williams and Murchie 1995). By killing natural enemies, pesticide applications must be increased further to achieve pest control (Pickett et al. 1995, Murchie et al. 1997). Parasitoids can control the pests. For example, more than 30 species of hymenopterous parasitoids have been reported to attack C. assimilis in Europe (Williams 2003). Of these, the larval ectoparasitoid Trichomalus perfectus Walker (Hymenoptera: Pteromalidae) is widely distributed and particularly important (Lerin 1987, Murchie and Williams 1998a). In addition to killing larvae through direct parasitism, it further kills by host feeding, and reduces damage to infested pods by preventing host larvae from eating their full complement of seeds (Murchie and Williams 1998b). Host selection by parasitoids may be influenced by plant characteristics (Vinson 1976) and plant architecture may alter parasitoid searching efficiency (Billqvist and Ekbom 2001a,b).

Unlike parasitoids, predators are usually nonspecific and their attacks on pests within oilseed rape crops tend to be fortuitous rather than targeted (Büchs 2003a). In oilseed rape fields, the dominant predators are carabids, these having the greatest biomass in comparison with rove beetles and spiders (Goltermann 1994). They are present all year round and can suppress pest populations at an early stage (Büchs 2003a). Over 20 species of carabid occur regularly in European oilseed rape fields. The species' composition within communities varies from country to country and also from site to site, according to regional or local conditions; changes have also occurred over time, with larger species (e.g. Carabus spp.) being less abundant now than formerly. The occurrence of carabids is greatly influenced by the farming system, being greater in extensively-managed than in intensively-managed crops (Hokkanen and Holopainen 1986, Büchs 2003b).

Recent advances in the management of oilseed rape pests have emphasised the important role of natural enemies within integrated pest management systems for the crop (Williams 2004). The EU-funded project MASTER: MAnagement STrategies for European Rape pests aims to develop economically-viable and environmentallyacceptable crop management strategies for winter oilseed rape which maximise the biological control of key pests and minimise chemical inputs (Williams et al. 2002). This requires much greater knowledge of pest, parasitoid and predator taxonomy and biology throughout Europe. In Estonian conditions, the pests of oilseed rape and their natural enemies have been little studied. The present pilot study aims to add to knowledge of rape pests and their natural enemies in Estonia and contributes to the project MASTER.

The aim of this pilot study was to compare the effects of minimised (no plough, direct drilling, no pesticides) and standard (plough, standard application of pesticides) cropping systems on oilseed rape plant architecture and the occurrence of pests, their hymenopteran parasitoids and carabid predators.

\section{Material and methods}

\section{The study site}

The study compared a minimised (MIN) with a standard (STN) system of cropping spring oilseed rape in 2003. The study site comprised two adjacent, approximately rectangular fields (both $2 \mathrm{ha}$ ) on Pilsu Farm, Tartu County, Estonia (58 $14^{\prime}$ latitude $26^{\circ} 16^{\prime}$ longitude). The soil was loamy (average $\mathrm{pH}$ KCI 6.15). In both fields, spring oilseed rape cv. Quantum (seeding rate $6 \mathrm{~kg} \mathrm{ha}^{-1}$ ) was drilled on 12 May, following winter wheat. 
Vol. 15 (2006): 61-72.

In the STN system, ploughing and pesticides were used. The herbicide Treflan Super $\left(21\right.$ ha $\left.^{-1}\right)$ was applied before drilling, and the herbicide Lontrel $300\left(0.31 \mathrm{ha}^{-1}\right)$ was applied at the two-leaf growth stage (BBCH-stage) $(\mathrm{BBCH} 12$ of Meier (2001), Lancashire et al. (1991)). The fungicide Folicur $\left(11 \mathrm{ha}^{-1}\right)$ was applied at BBCH 50-51 and the insecticide Fastac $\left(0.151\right.$ ha $\left.^{-1}\right)$ at BBCH 65-66. In the MIN system, direct drilling replaced ploughing and no pesticides were used.

The fields were bordered to the north by an asphalt road, with a $10 \mathrm{~m}$ strip of barley between the road and the oilseed rape, to the south by winter wheat, to the west by grassland and to the east by a crop of barley. The MIN field had many weeds, dominated by Tripleurospermum inodorum (L.), Stellaria media (L.) and Galeopsis tetrahit L. In the STN field, Capsella bursa-pastoris (L.) was abundant.

In 2003, spring/summer weather was warmer and wetter than average. Data from the local meteorological station at Eerika, near Tartu showed that May temperatures (mean $11.6^{\circ} \mathrm{C}$ ) were $1.4^{\circ} \mathrm{C}$ and July temperatures (mean $19.4^{\circ} \mathrm{C}$ ) were $1.5^{\circ} \mathrm{C}$ warmer than the long-term average. Rainfall in May (mean $142.8 \mathrm{~mm}$ ) was 2.3 times greater, and in August (mean $132.8 \mathrm{~mm}$ ) almost 2 times greater than the long term average. The warm, moist spring promoted the growth and development of the rape crop whereas the wet August inhibited crop ripening and harvesting.

\section{Insect sampling}

Insects were sampled using water and pitfall traps emptied weekly from post-drilling (14 May) to preharvest (27 August). The water traps (4 in STN and 4 in MIN), consisted of yellow plastic bowls $(210 \times$ $310 \times 90 \mathrm{~mm}$ ), each containing about 1.51 water. They were positioned at the top of the crop canopy to sample flying insects and raised weekly, as necessary, to keep pace with crop growth. Four were placed within the crop $15 \mathrm{~m}$ from different borders and two were placed outwith the crop. Pitfall traps for sampling carabids were placed along a central transect of each field (5 in STN and 5 in MIN).
Insect samples were sorted and target taxa identified and counted in the laboratory. The crucifer-specialists, hymenopterous parasitoids and ground beetles were separated and stored in $70 \%$ ethanol at $-18^{\circ} \mathrm{C}$. The target phytophagous insects and carabids were identified to species. Hymenopterous parasitoids were identified to family, except those specialised on the target phytophagous insects, which were identified to species.

\section{Plant sampling}

The growth stages of the rape plants in both crops were recorded weekly using the Meier (2001) key. Plant density, architecture and infestation and damage by pests were also determined in both crops. Oilseed rape plant and weed density per $\mathrm{m}^{2}$ was determined from 5 randomly-selected places in both fields on two occasions (BBCH 12 and 69-71). Plant architecture and pest infestation was determined on 10 plants from 5 randomly-chosen locations (50 plants from STN and 50 from MIN) collected on 21 August (BBCH 83). Each plant was measured (stem height and diameter and the number of pods and podless stalks on the main raceme and side branches). Damage caused by $M$. aeneus was assessed as the number of podless stalks (podless stalks in the very top of the stem were not counted because this may have been caused by other factors, e.g. lack of pollination). Stems were dissected for $C$. pallidactylus larval mining damage. Pods were examined for the presence of live or dead C. assimilis and D. brassicae larvae, the exit holes of emerged $C$. assimilis larvae or those of its ectoparasitoids or pod shatter due to D. brassicae larvae.

\section{Statistical analysis}

Although only one field with each cropping system was observed the data were analysed using the following statistical methods because all other conditions in the two fields were similar. Statistical analysis used SAS GLM and GENMOD procedures. The differences of means of plant parame- 
Veromann, E. et al. Oilseed rape insects in Estonia

ters and the numbers of oilseed rape and weed plants per $\mathrm{m}^{2}$ were compared with analysis of variance. Comparisons of the numbers of pests, parasitoids and carabids were made using type 3 empirical standard errors analysis and the Poisson distribution and the $\log$ link function. The numbers of pests and carabids caught each week were also analysed separately. For analyses of the numbers of carabids the scale parameter was estimated by Pearson's Chi-Square divided by the degrees of freedom because of overdispersion of the model.

\section{Results}

\section{Plant density, architecture and pest damage}

Plant density was similar in both crops, early in development (BBCH 12; MIN, mean 86.3 per m² $^{2}$,

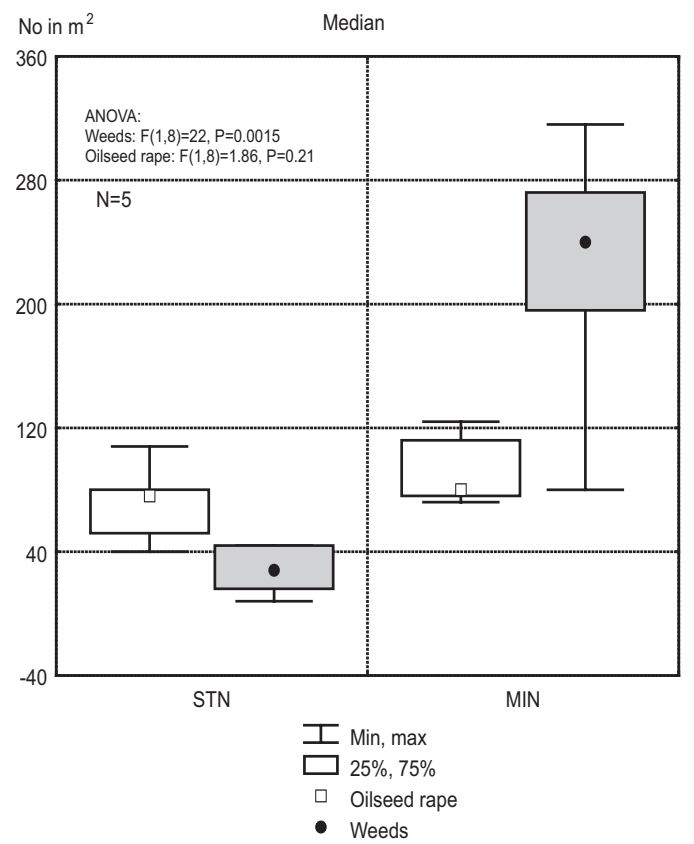

Fig. 1. The median number of oilseed rape plants $(\mathrm{BBCH}$ 69-71) and weeds per $\mathrm{m}^{2}$ in standard (STN) and minimised cropping system (MIN) fields on Pilsu Farm, Tartu County, Estonia in 2003.
STN, mean 91.3 per $\left.\mathrm{m}^{2}\right)$, as well as later, $(\mathrm{BBCH}$ 69-71), however, there were significantly more weeds in the MIN field ( $\mathrm{P}=0.0015)$ (Fig. 1). The dominating weed was $T$. inodorum.

Stem height, stem diameter and the number of side branches were similar in the MIN and the STN crop. However, main raceme and side branches of the MIN plants had significantly ( $\mathrm{P}=0.043$ and $\mathrm{P}=0.0016$ ) fewer pods than those of the STN plants (Fig. 2). Damage by M. aeneus, assessed as podless stalks, was less in the STN than in the MIN field (Fig. 2). Few pods were damaged by C. assimilis and damage was similar between treatments ( $1 \%$ of 4208 dissected pods from STN field and $0.5 \%$ of 2740 dissected pods from MIN field). No infestation by $D$. brassicae was found.

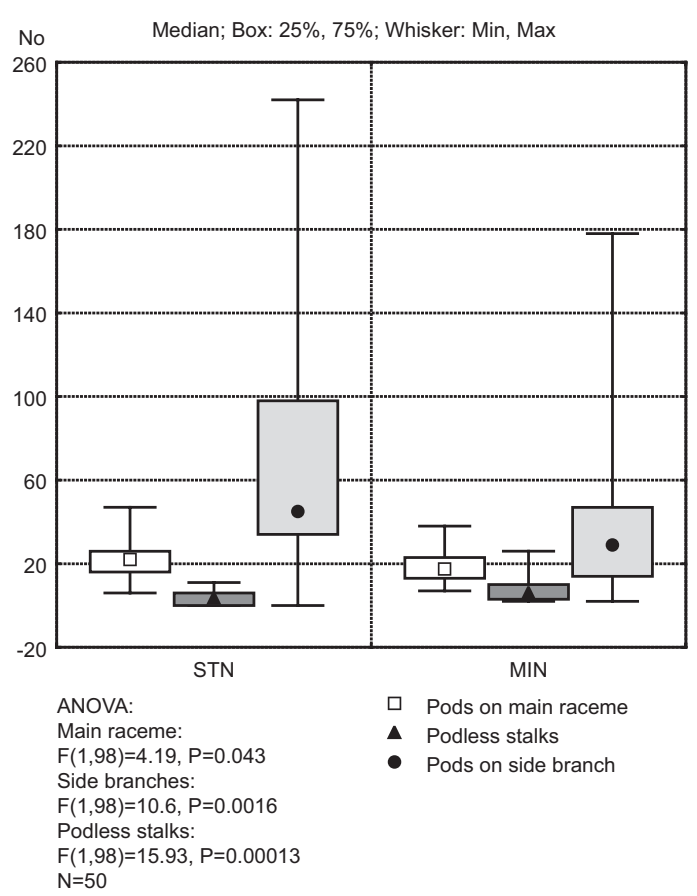

Fig. 2. The median number of podless stalks on the main raceme, of pods on the main raceme and on side branches on rape plants grown using a standard cropping system (STN) and a minimised cropping system (MIN) on Pilsu Farm, Tartu County, Estonia, in 2003. 
Vol. 15 (2006): 61-72.

\section{Pest incidence and phenology}

During the study, 60 samples with a total of 2,588 specimens of crucifer-specialist insect pests from eight taxa (Table 1) were collected from the water traps (MIN, 792 specimens; STN 1,796 specimens).

Meligethes aeneus started to colonise the oilseed rape from $\mathrm{BBCH} 12$ (Fig. 3), increasing from 12 June (BBCH 14) and showing two popu- lation peaks, on 2 July and 13 August. The first peak coincided with first flower (BBCH 59-60). The second occurred during pod ripening $(\mathrm{BBCH}$ $80-81$ ). At both peaks and throughout the study period, $M$. aeneus abundance was greater in the STN field than in the MIN field (Fig. 4, $\chi^{2}=11.04$, $\mathrm{df}=1, \mathrm{P}=0.0009$ ).

Ceutorhynchus assimilis abundance was low on both crops (Fig. 4). The first were found on 12 June (BBCH 14). There were two population

Table 1. The species' composition and the mean number of crucifer-specialists caught in yellow water traps (4 per system, $\mathrm{N}=60$ ) in spring oilseed rape grown using a standard and a minimised cropping system on Pilsu Farm, Tartu County, Estonia, in 2003.

\begin{tabular}{|c|c|c|c|c|c|}
\hline \multirow[t]{3}{*}{ Species } & \multicolumn{4}{|c|}{ Cropping system } & \multirow[t]{3}{*}{$\mathrm{P}$ value } \\
\hline & \multicolumn{2}{|c|}{ Minimised } & \multicolumn{2}{|c|}{ Standard } & \\
\hline & Mean & Std. dev & Mean & Std. dev & \\
\hline Meligethes aeneus & 11.83 & 17.44 & 25.60 & 53.26 & $\mathrm{P}<0.0009$ \\
\hline Meligethes viridescens & 0.42 & 1.01 & 0.63 & 1.06 & \\
\hline Ceutorhynchus assimilis & 0.27 & 0.58 & 0.85 & 1.79 & $\mathrm{P}<0.0001$ \\
\hline Ceutorhyncuhs rapae & 0.23 & 0.67 & 1.43 & 4.48 & $\mathrm{P}<0.0001$ \\
\hline Ceutorhynchus floralis & 0.03 & 0.18 & 0.02 & 0.13 & \\
\hline Ceutorhynchus pallidactylus & 0.00 & 0.00 & 0.02 & 0.13 & \\
\hline Ceutorhynchus pleurostigma & 0.02 & 0.13 & 0.00 & 0.00 & \\
\hline Phyllotreta & 0.40 & 1.64 & 1.32 & 3.68 & \\
\hline
\end{tabular}

Fig. 3. The median numbers of Meligethes aeneus per yellow water trap caught at different growth stages $(\mathrm{BBCH})$ in standard (STN) and minimised (MIN) cropping system fields of spring oilseed rape on the Pilsu Farm, Tartu County, Estonia, in 2003 (* indicates significant difference between systems).

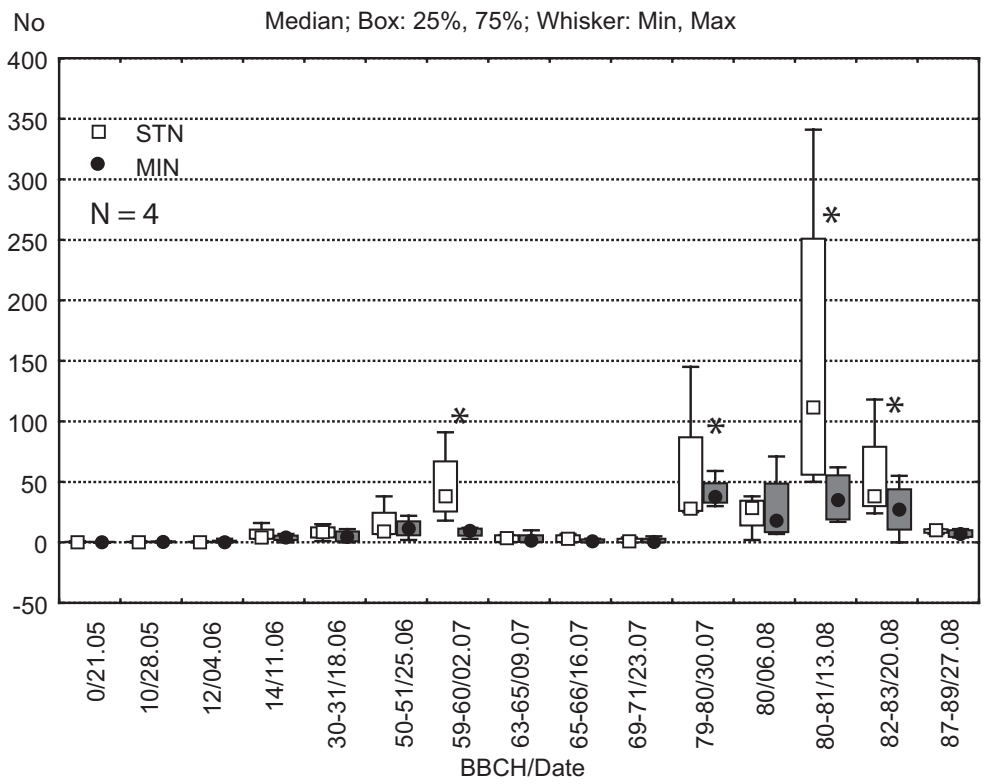


Veromann, E. et al. Oilseed rape insects in Estonia

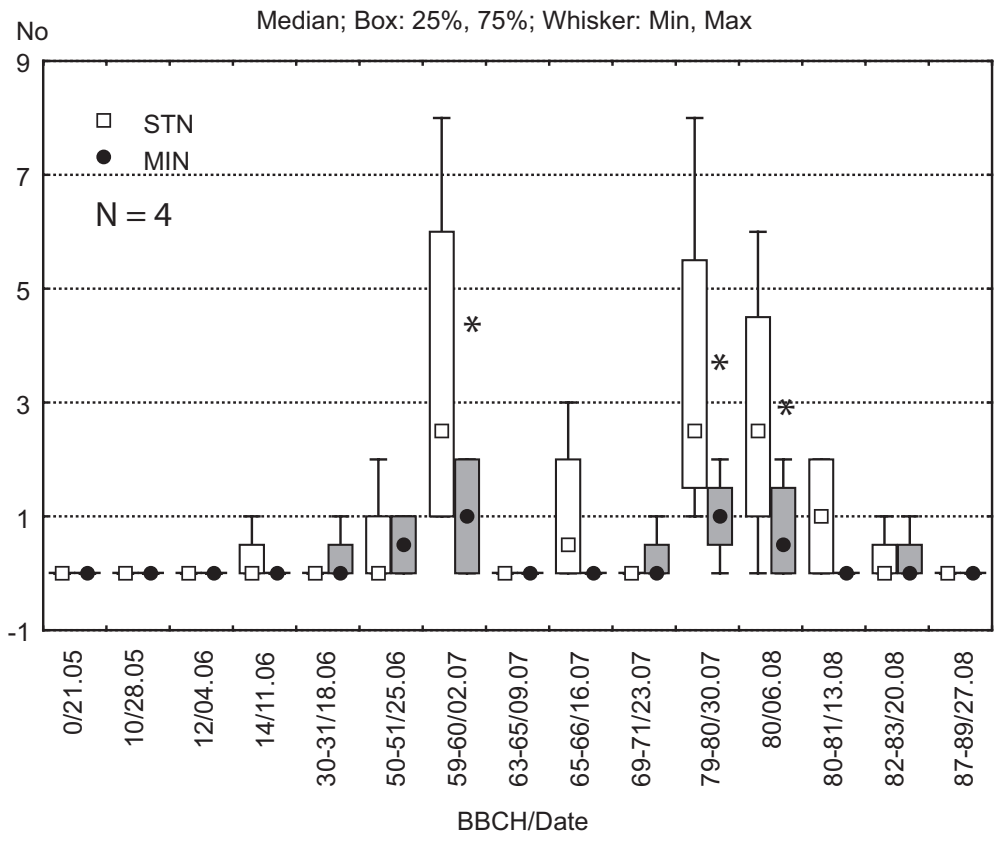

Fig. 4. The median numbers of Ceutorhynchus assimilis per yellow water trap caught at different rape growth stages $(\mathrm{BBCH})$ in standard (STN) and minimised (MIN) cropping systems fields of spring oilseed rape on Pilsu Farm, Tartu County, Estonia, in 2003 (* indicates significant difference between systems). peaks, the first at first flower (BBCH 59-60) and the second during pod maturation (BBCH 79-80). Abundance was greater in the STN field than in the MIN field (Fig. 5, $\chi^{2}=26.02$, df $=1, \mathrm{P}<0.0001$ ).

\section{Parasitoid incidence and phenology}

Hymenopteran parasitoids from six superfamilies and 18 families were captured in the water traps (MIN, 828 specimens; STN, 660 specimens). Amongst them were four parasitoids of M. aeneus: Diospilus capito, Phradis morionellus, Phradis interstitialis and Tersilochus heterocerus and two parasitoids of $C$. assimilis: Mesopolobus morys and T. perfectus (Table 2).

The number of parasitoids increased as the rape started to flower (BBCH 59-60). At full flower, numbers were greater in the STN than in MIN field (Fig. 5). The parasitoid population reached maximum during pod ripening (BBCH 79-80) in the MIN field. The numbers of key parasitoids caught from the two cropping systems were similar and not large. Of the M. aeneus endoparasi- toids, D. capito, P. morionellus, $P$. interstitialis and T. heterocerus, totals of 47 and 51 specimens were found in the STN and the MIN field, respectively. Of the $C$. assimilis parasitoids, M. morys and T. perfectus, only one specimen was found in STN field and 3 specimens in MIN field. Peak abundance of D. capito, the endoparasitoid of M. aeneus larvae, coincided with peak abundance of new generation $M$. aeneus (BBCH 80-83). Peak abundance of $P$. morionellus, $P$. interstitialis and $T$. heterocerus, coincided with $M$. aeneus colonisation. A total of only three specimens of T. perfectus, and one specimen of $M$. morys, both ectoparasitoids of $C$. assimilis larvae, were found.

\section{Carabid incidence and phenology}

During the study, 150 pitfall trap samples were collected, containing a total of 3,045 carabids. Activity-density was greater in the MIN than in the STN field (from MIN 2169 and STN 876 specimens; $\chi^{2}=6.27 ; \mathrm{df}=1 ; \mathrm{P}=0.0123$ ) (Table 3 ). In the MIN field, maximal activity-density of cara- 
Vol. 15 (2006): 61-72.

Table 2. Total numbers of hymenopteran parasitoids caught in yellow water traps (4 per system) in standard and minimised cropping system fields of spring oilseed rape on Pilsu Farm, Tartu County, Estonia, in 2003.

\begin{tabular}{|c|c|c|c|}
\hline Superfamily & Family/Species & Standard & Minimised \\
\hline \multirow{9}{*}{ Chalcidoidea } & Eulophidae & 32 & 55 \\
\hline & Eurytomidae & 15 & 9 \\
\hline & Pteromalidae & 163 & 344 \\
\hline & Trichomalus perfectus (Walker) & 1 & 2 \\
\hline & Mesopolobus morys (Walker) & 0 & 1 \\
\hline & Mymaridae & 25 & 16 \\
\hline & Encyrtidae & 41 & 35 \\
\hline & Eupelmidae & 1 & 1 \\
\hline & Trichogramatidae & 0 & 1 \\
\hline \multirow[t]{2}{*}{ Platygastroidea } & Platygastridae & 83 & 65 \\
\hline & Scelionidae & 43 & 40 \\
\hline \multirow[t]{7}{*}{ Ichnemonoidea } & Braconidae & 34 & 61 \\
\hline & Diospilus capito (Nees) & 6 & 1 \\
\hline & Ichnemonidae & 60 & 65 \\
\hline & Tersilochus tripartitus (Brischke) & 1 & 3 \\
\hline & Tersilochus heterocerus Thomson & 0 & 1 \\
\hline & Phradis morionellus (Holmgren) & 22 & 42 \\
\hline & Phradis interstitialis (Thomson) & 19 & 7 \\
\hline \multirow[t]{2}{*}{ Cerphronoidea } & Megaspilidae & 3 & 4 \\
\hline & Ceraphronidae & 100 & 56 \\
\hline \multirow[t]{2}{*}{ Proctotrupoidea } & Proctotrupidae & 3 & 2 \\
\hline & Diapriidae & 1 & 9 \\
\hline \multirow[t]{4}{*}{ Cynipoidea } & Eucoilidae & 6 & 6 \\
\hline & Cynipidae & 0 & 2 \\
\hline & Figitidae & 1 & 0 \\
\hline & Total & 660 & 828 \\
\hline
\end{tabular}

Fig. 5. The median numbers of hymenopteran parasitoids per yellow water trap caught at different rape growth stages $(\mathrm{BBCH})$ in standard (STN) and minimised (MIN) cropping system fields of spring oilseed rape on the Pilsu Farm, Tartu County, Estonia, in 2003.

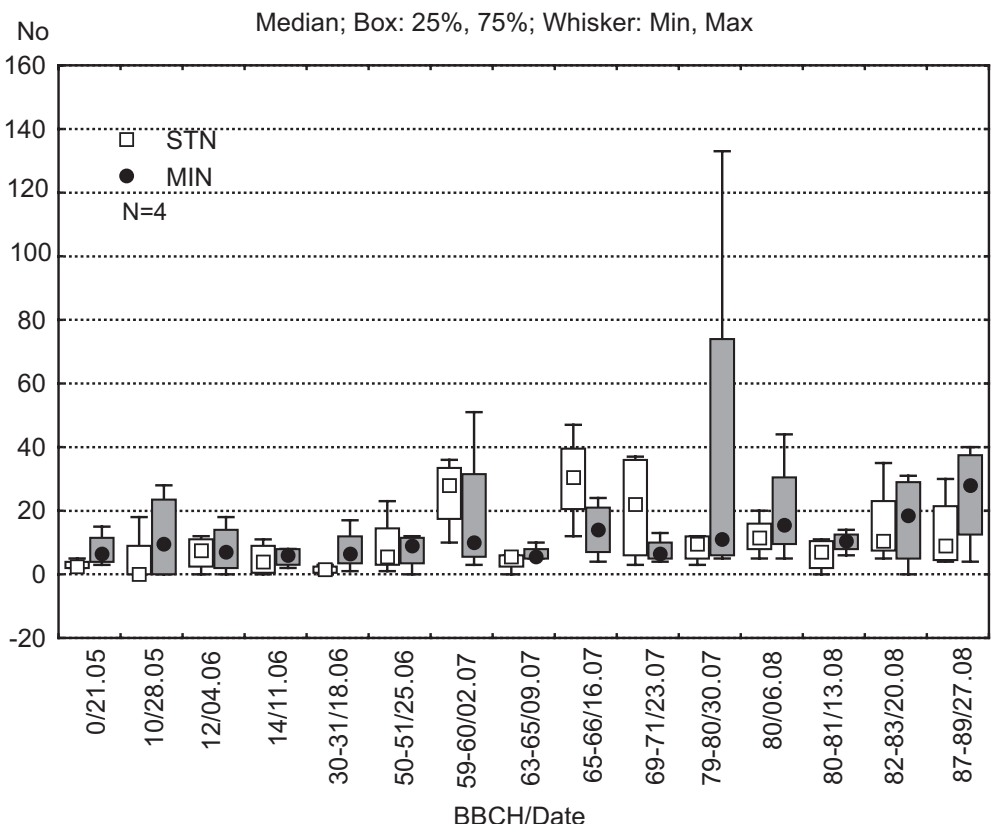


Veromann, E. et al. Oilseed rape insects in Estonia

Table 3. The species composition and mean number of carabids caught with pitfall traps ( 5 per system, $\mathrm{N}=75$ ) in standard and minimised cropping system fields of spring oilseed rape on Pilsu Farm, Tartu County, Estonia, in 2003.

\begin{tabular}{|c|c|c|c|c|c|}
\hline \multirow[t]{3}{*}{ Species } & \multicolumn{4}{|c|}{ Cropping system } & \multirow[t]{3}{*}{$\mathrm{P}<0.05$} \\
\hline & \multicolumn{2}{|c|}{ Standard } & \multicolumn{2}{|c|}{ Minimised } & \\
\hline & Mean & Std dev & Mean & Std dev & \\
\hline Pseudoophonus rufipes (Degeer) & 16.64 & 29.81 & 6.33 & 8.80 & * \\
\hline Harpalus affinis (Schrank) & 0.20 & 0.44 & 0.16 & 0.49 & \\
\hline Poecilus cupreus (Linnaeus) & 5.39 & 11.94 & 1.91 & 3.06 & * \\
\hline Pterostichus melanarius (Illiger) & 3.72 & 5.15 & 0.69 & 1.39 & $*$ \\
\hline Pterostichus niger (Schaller) & 0.60 & 1.38 & 0.07 & 0.30 & \\
\hline Agonum muelleri (Herbst) & 0.85 & 1.92 & 0.19 & 0.67 & \\
\hline Anchomenus dorsalis (Pontoppidan) & 0.32 & 0.89 & 0.47 & 1.55 & \\
\hline Clivina fossor (Linnaeus) & 0.19 & 0.46 & 0.15 & 0.39 & \\
\hline Calathus melanocephalus (Linnaeus) & 0.03 & 0.16 & 0.59 & 3.60 & \\
\hline Amara aulica (Panzer) & 0.28 & 1.20 & 0.03 & 0.16 & \\
\hline Amara spp & 0.01 & 0.12 & 0.00 & 0.00 & \\
\hline Amara fulva (Müller) & 0.01 & 0.12 & 0.03 & 0.16 & \\
\hline Amara bifrons (Gyllenhal) & 0.11 & 0.45 & 0.20 & 0.66 & \\
\hline Carabus cancellatus (Illiger) & 0.05 & 0.23 & 0.08 & 0.27 & \\
\hline Bembidion properans (Stephens) & 0.37 & 0.82 & 0.51 & 1.01 & \\
\hline Bembidion quadrimaculatum (Linnaeus) & 0.00 & 0.00 & 0.03 & 0.16 & \\
\hline Bembidion lampros (Herbst) & 0.11 & 0.35 & 0.05 & 0.23 & \\
\hline Acupalpus meridianus ( Linnaeus) & 0.00 & 0.00 & 0.01 & 0.12 & \\
\hline Calathus erratus (Sahlberg) & 0.03 & 0.16 & 0.19 & 0.59 & \\
\hline Asaphidion pallipes (Duftschmid) & 0.01 & 0.12 & 0.01 & 0.12 & \\
\hline
\end{tabular}

bids was reached at the end of rape flowering (BBCH 69) (Fig. 6). The three most abundant species in both the MIN and the STN fields were Pseudoophonus rufipes, Poecilus cupreus and Pterostichus melanarius. Pseudoophonus rufipes was the dominant carabid species caught, constituting more than half of all specimens in both fields. Poecilus cupreus was the second most abundant species. Both of them were caught significantly more in the MIN than in the STN field $(P$. rufipes: $\chi^{2}=5.71 ; \mathrm{df}=1 ; \mathrm{P}=0.0169 ;$ P. cupreus: $\left.\chi^{2}=5.90 ; \mathrm{df}=1 ; \mathrm{P}=0.0151\right)$ and their activitydensity peak coincided with $M$. aeneus larval drop at the end of rape flowering (BBCH 69) (Fig. 6).

\section{Discussion}

During the study, the three major European pests of oilseed rape: M. aeneus, C. assimilis and C. pallidactylus (one specimen only) were collected.
Meligethes aeneus was by far the most numerous and the only one to reach pest status. The second most abundant pest was $C$. assimilis. A few $M$. viridescens were also caught; this species requires higher temperatures for oviposition and development than M. aeneus (Alford et al. 2003). In addition, Ceutorhynchus rapae, C. floralis, C. pleurostigma and flea beetles (Phyllotreta spp.) were also captured but their abundance was low. Ceutorhynchus rapae is infrequently recorded in Estonia (Metspalu and Hiiesaar 2002) and therefore the relative large number caught (totally 50 , in $\mathrm{BBCH}$ 12 in STN field) was unusual. Insect incidence on oilseed rape is dependent on several factors, such as oilseed rape plant architecture, presence of flowering weeds, crop rotations, landscape structure etc. (Walters et al. 2003). Weeds can exert direct stress on crops (by competing for sunlight, moisture etc.) or affect indirectly through enhancing the presence of the natural enemies of pests (Altieri and Nicholls 2004). In our study, oilseed rape plant density was similar in both crops but there were significantly more weeds in the MIN 
Vol. 15 (2006): 61-72.

Fig. 6. The median numbers of carabids per pitfall trap caught at different rape growth stages $(\mathrm{BBCH})$ in standard (STN) and minimised (MIN) cropping system fields of spring oilseed rape on Pilsu Farm, Tartu County, Estonia, in 2003 (* indicates significant difference between systems).

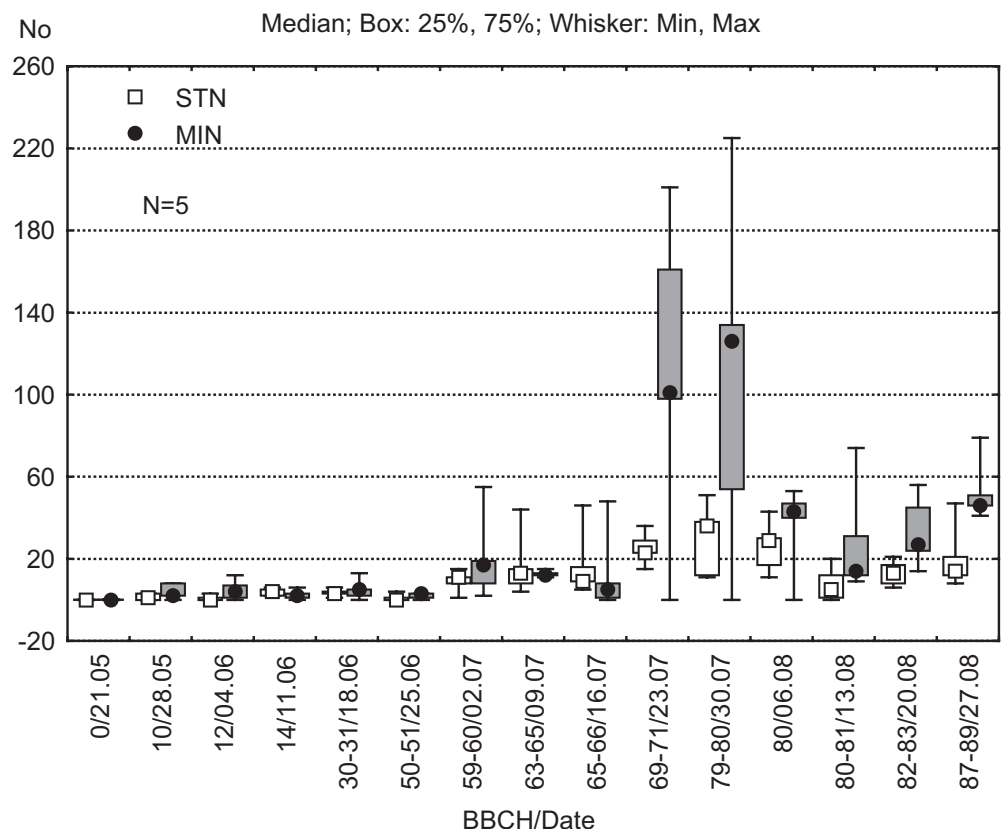

field. The weeds were large enough to compete with the crop plants for food and light, probably accounting for the reduction in the number of flowers on the side branches of the rape plants in the MIN compared with the STN field. The greater abundance of rape flowers in the STN field provided a greater food resource for $M$. aeneus so their damage to the main raceme was lower in the STN than in the MIN field, where the beetles concentrated on the main raceme on the plants.

The two most numerous pests, M. aeneus and C. assimilis, each had two population peaks at approximately the same time, the first at first flower (BBCH 59-60) and the second during pod ripening (BBCH 80-81). The second peak indicated emergence of the new generation from the soil. Despite the application of insecticide to the STN field at $\mathrm{BBCH} 65$ pest abundance was greater in the STN field than in the MIN field throughout the study period. This could be explained by differences in crop performance in the case of $M$. aeneus, and in the case of $C$. assimilis, by the greater resource of young pods for oviposition. The cropping system appears to have influenced rape plant architecture, enabling plants in the STN field to produce more flowers than those in the MIN field, which in turn resulted in greater infestation by $M$. aeneus and $C$. assimilis in the former.

Parasitoids of both of key pests were found. Four parasitoids of M. aeneus: D. capito, P. morionellus, $P$. interstitialis and T. heterocerus and two parasitoids of C. assimilis: M. morys and T. perfectus were captured. All are recorded for the first time in Estonia (Tryapitzyn 1978, Kasparjan 1981). These parasitoid species are found over most of Europe, from southern Sweden to France (Nilsson 2003, Williams 2003) with those of $M$. aeneus at the northern distribution limit of oilseed rape in Finland (Hokkanen 1989). The distribution and abundance of different species depends on factors such as the local climate, the crops grown during previous years and the cultivation techniques used (Nilsson 2003). At full flower, the number of parasitoids was greater in the STN than in MIN field, probably attracted by the greater abundance of flowers; adult parasitoids are exclusively dependent on floral and extrafloral nectar, honeydew and pollen for food (Lewis et al. 1998). During 


\section{AGRICULTURAL AND FOOD SCIENCE}

Veromann, E. et al. Oilseed rape insects in Estonia

pod ripening (BBCH 79-80), the further increase in the number of parasitoids in the MIN field probably indicated the emergence of new generations of some hymenopteran parasitoid species. Key parasitoid phenology was synchronised with that of their hosts. Peak abundance of D. capito, coincided with peak abundance of new generation $M$. aeneus (BBCH 80-83), indicating that they probably emerged from host larvae in the oilseed rape. Diospilus capito is multivoltine with two or three generations in northern Europe (Billquist and Ekbom 2001a, Nilsson 2003). The other captured parasitoids of $M$. aeneus have one generation per year and after pupating in the host pupal chamber in the soil stay in diapause in the cocoon until the following spring or summer (Nilsson 2003); they were found at the same time as M. aeneus colonised. Due to the low abundance of $C$. assimilis a very few of its parasitoids were found also. Trichomalus perfectus is a univoltine ectoparasitoid reported, in winter rape, to have an abundance peak two to four weeks after peak migration of $C$. assimilis into the crop. New-generation parasitoids mate on emergence and leave the crop shortly before harvest. Only females overwinter, possibly in evergreen foliage (Williams 2003). In Estonia, the total number of key parasitoids was very low probably because the history of oilseed cropping is short and the parasitoids may need more time to build up their populations. Although their greater abundance in the MIN field suggests potential to encourage them with more environmentallyfriendly crop management, but this requires additional research.

Beside parasitoids, carabids also have potential to impact rape pest populations through predation. For example, fully-grown larvae of M. aeneus, drop to the ground for pupation, and are then important components of the diet of carabids (Büchs and Alford 2003). The MIN field had greater abundance of carabids than the STN field. This agrees with the findings of Hokkanen and Holopainen (1986), Langmaack et al. 2001 and Irmler (2003) who also found more individuals and species of carabids on biologically- or minimally-managed fields, which they ascribed to the availability of more prey. Also Altieri and Nicholls (2004) high- lighted the important role of weeds in the presence of predators in the fields. This could be true also for the present study, where the MIN field with its reduced tillage, no pesticides and more weeds offered greater food resources for carabids. Maximal activity-density of carabids in the MIN field was two weeks before the maximal abundance of the new generation of $M$. aeneus. This is the period when $M$. aeneus larvae are mature, drop to the soil to pupate, and are most vulnerable to predation. The three most abundant species in both fields: $P$. rufipes, $P$. cupreus and $P$. melanarius have been reported as typical of winter rape fauna (Langmaack et al. 2001, Luik et al. 2001). According to Thiele (1977), 50\% of the food consumed by $P$. rufipes is animal matter. Poecilus cupreus is an important predator of M. aeneus larvae (Büch 2002). Similarily to our data, Büchs and Nuss (2000) also found strong coincidence between the time of the occurrence of P. cupreus and P. melanarius and that of oilseed rape pest larvae during their change of strata for metamorphosis, and suggested that carabids are important larval predators. Predatory efficacy is greatly influenced by the time period over which carabids can prey upon M. aeneus larvae. With unlimited access to the larvae during the whole "dropping" period, mortality of larvae can be considerable (78\%) (Büchs 2003a). Delayed flowering of the crop, high density of pest larvae and longer duration of the larval "dropping" period enhances the positive effects of polyphagous epigaeic predators in oilseed rape (Büchs 2003a). Although there was more potential prey $(M$. aeneus larvae) in the STN field, there were significantly fewer carabids in the STN than in the MIN field. This was probably caused by insecticide treatment, to which carabids are known to be sensitive. Tuubel and Toom (1999) found that the treatment of a barley field with Fastac significantly decreased the numbers of Harpalus and Pterostichus. The application of Fastac to the STN field (BBCH 65-66) probably killed a proportion of the carabids either directly or via poisoned prey. Therefore activitydensity peak of carabids was obvious only in the MIN field, where their pressure on M. aeneus larvae was stronger. Thus, in the MIN system, the reduced abundance of new generation $M$. aeneus 
Vol. 15 (2006): 61-72.

and $C$. assimilis could have resulted from both the lower number of rape flowers and the greater mortality of pest larvae from the more abundant parasitoids and predators.

Acknowledgements. We thank Marge and Madis Ajaots, Pilsu Farm, for crop husbandry and two anonymous reviewers for constructive comments. This study was supported by the EU Framework 5 project MASTER: Integrated pest management strategies incorporating bio-control for European oilseed rape pests (QLK5-CT-200101447) and Estonian Science Foundation grants Nr 5736 and 4993. Rothamsted Research receives grant-aided support from the UK Biotechnology and Biological Sciences Research Council.

\section{References}

Alford, D.V., Murchie, A.K. \& Williams, I.H. 1995. Observations on the impact of standard insecticide treatments on Trichomalus perfectus, a parasitoid of seed weevil on oilseed rape in the UK. Bulletin IOBC wprs 18, 4: $122-126$.

Alford, D.V., Nilsson, C. \& Ulber, B. 2003. Insect pest of oilseed rape crops. In: Alford, D.A. (ed.). Biocontrol of oilseed rape pests. Oxford, UK: Blackwell Science Ltd. p. 10-41.

Altieri, M.A. \& Nicholls, C.I. 2004. Biodiversity and pest management in agroecosystems. 2nd ed. Food Products Press. $236 \mathrm{p}$.

Billqvist, A. \& Ekbom, B. 2001a. Effects of host plant species on the interaction between the parasitic wasp Diospilus capito and pollen beetles (Meligethes spp.). Agricultural and Forest Entomology 3: 147-152.

Billqvist, A. \& Ekbom, B. 2001b. The influence of host plant species on the parasitism of pollen beetles (Meligethes spp.) by Phradis morionellus. Entomologia Experimentalis et Applicata 98: 41-47.

Büch, R. 2002. Mortality of pollen beetle (Meligethes spp.) larvae due to predators and parasitoids in rape fields and the effect of conservation strips. Agriculture, Ecosystems and Environment 90: 225-263.

Büchs, W. 2003a. Predators as biocontrol agents of oilseed rape pests. In: Alford, D.A. (ed.). Biocontrol of oilseed rape pests. Oxford, UK: Blackwell Science Ltd. p. 279298.

Büchs, W. 2003b. Impact of on-farm landscape structures and farming systems on predators. In: Alford, D.A. (ed.). Biocontrol of oilseed rape pests. Oxford, UK: Blackwell Science Ltd. p. 245-227.

Büchs, W. \& Nuss, H. 2000. First steps to assess the importance of epigaeic active polyphagous predators on oilseed rape insects pests with soil pupating larvae. Bulletin IOBC wprs 23, 6: 151-163.
Goltermann, S. 1994. Das auftreten von laufkäfern (Col. Carabidae) auf winterrapsfeldern und deren einfluss auf den massenwechsel von Meligethes aeneus $F$. (Col. Nitulidae). PhD thesis, University of Rostock, Germany.

Hokkanen, H. 1989. Biological and agrotehnical control of the rape blossom beetle Meligethes aeneus (Col., Nitid.). Acta Entomologica Fennica 53: 25-29.

Hokkanen, H. \& Holopainen, J.K. 1986. Carabid species and activity densities in biologically and conventionally managed cabbage fields. Journal of Applied Entomology 52: 209-254.

Irmler, U. 2003. The spatial and temporal pattern of carabid beetles on arable fields in northen Germany (Schleswig-Holstein) and their value as ecological indicators. Agriculture, Ecosystems and Environment 98: 141151.

Kasparjan, D.R. (ed.). 1981. Keys to the insect of the European part of the USSR, Volume III, Hymenoptera, Part III. Nauka: 688. (in Russian).

Lancashire, P.D., Bleiholder, H., Boom, T.D. van, Langelüddeke, P., Strauss, P., Weber, E. \& Witzenberger, A. 1991. A uniform decimal code for stages of crops and weeds. Annals of Applied Biology 119: 561-601.

Langmaack, M., Land, S. \& Büchs, W. 2001. Effects of different field management systems on the carabid coenosis in oilseed rape with special respect to ecology and nutritional status of predacious Poecilus cupreus L. (Coleoptera, Carabidae). Journal of Applied Entomology 125: 313-320.

Lerin, J. 1987. A short bibliographical review of Trichomalus perfectus Walker, a parasite of the seed pod weevil Ceutorhynchus assimilis Payk. Bulletin IOBC wprs 10: 74-78.

Lewis, W.J., Stapel, J.O., Cortesero, A.M. \& Takasu, K. 1998. Understanding how parasitoids balance food and host needs: importance to biological control. Biological Control 11: 175-183.

Luik, A., Tarang, T. \& Voolma, K. 2001. Carabids in reforestation areas and in the winter rape field of the forest neighbourhood. Journal of Forest Science 47: 123126.

Meier, U. (ed.) 2001. Growth stages of mono- and dicotyledonous plants. 2nd ed. Updated 23 Nov 2003. Cited 5 Dec 2005. Available on the Internet: http://www.bba. de/veroeff/bbch/bbcheng.pdf

Metspalu, L. \& Hiiesaar, K. 2002. Ristõieliste kultuuride kahjurid. EPMÜ Taimekaitse Instituut, Tartu. p. 102.

Murchie, A.K. \& Williams, I.H. 1998a. A bibliography of the cabbage seed weevil. Bulletin IOBC wprs 21: 163-169.

Murchie, A.K. \& Williams, I.H. 1998b. Effect of host size on the sex of Trichomalus perfectus. Bulletin IOBC wprs 21: 177-181.

Murchie, A.K., Williams, I.H. \& Alford, D.V. 1997. Effects of commercial treatments to winter oilseed rape on parasitism of Ceutorhynchus assimilis Paykull (Coleoptera: Curculionidae) by Trichomalus perfectus (Walker) (Hymenoptera: Pteromalidae). Crop Protection 16: 199202.

Nilsson, C. 2003. Parasitoids of pollen beetles. In: Alford, D.A. (ed.). Biocontrol of oilseed rape pests. Oxford, UK: Blackwell Science Ltd. p. 73-85. 


\section{AGRICULTURAL AND FOOD SCIENCE}

Veromann, E. et al. Oilseed rape insects in Estonia

Pickett, J.A., Butt, T. M., Wallsgrove, R.M. \& Williams, I.H. 1995. Minimising pesticide input in oilseed rape by exploiting natural regulatory processes. In: Proceedings of the 9th International Rapeseed Congress. Cambridge. p. 565-571.

Statistics Board 2003. Add the title of the statistics. Updated 22 July 2005. Cited 20 October 2005. Available on the Internet: http://pub.stat.ee/px-web.2001/Database/Majandus/Majandus.asp.

Thiele, H.-V. 1977. Carabid beetles in their enviroments. Zoophysiology and ecology 10. A study on habitat selection by adaptations in physiology and behaviour. Springer-Verlag, Berlin, Heidelberg, New York. 160 p.

Tryapitzyn, V.A. (ed.). 1978. Keys to the insect of the European part of the USSR, Volume III, Hymenoptera, Part II. Nauka: 758. (in Russian).

Tuubel, E. \& Toom, T. 1999. The influence of pesticides on arthropod predators fauna. Transactions of the Estonian Agricultural University 203: 180-183.

Walters K.F.A., Young, J.E.B., Kromp, B. \& Cox, P.D. 2003.
Management of oilseed rape pests. In: Alford, D.A. (ed.). Biocontrol of oilseed rape pests. Oxford, UK: Blackwell Science Ltd. p. 43-71.

Williams, I.H. 2003. Parasitoids of cabbage seed weevil. In: Alford, D.A. (ed.). Biocontrol of oilseed rape pests. Oxford, UK: Blackwell Science Ltd. p. 97-112.

Williams, I.H. 2004. Advances in insect pest management of oilseed rape in Europe. In Horowitz, A.R. \& Ishaaya, I. (eds.). Insect pest management - field and protected crops. Springer-Verlag: Heidelberg. p. 181-208.

Williams, I.H., Büchs, W. Hokkanen, H., Johnen, A., Klukowski, Z., Luik, A., Nilsson, C. \& Ulber, B. 2002. MASTER: management strategies for European rape pests - a new EU Project. In: The BCPC Conference 18-21 November 2002. Conference Proceedings Vol. 2, Brighton, UK. p. 641-646.

Williams, I.H. \& Murchie, A.K. 1995. The role of parasitoids. Agronomist, Spring 1995. p. 13-15.

Vinson, S.B. 1976. Host selection by insect parasitoids. Annual Review of Entomology 21: 109-133. 